\title{
Identification and Epidemic Distribution of Two Flavescence Dorée-Related Phytoplasmas in Veneto (Italy)
}

\author{
Marta Martini and Ermanno Murari, UCI-STAA Patologia Vegetale, University of Bologna, 40126, Bologna \\ Italy; Nicola Mori, Istituto di Entomologia Agraria, University of Padova, 35020, Legnaro, PD, Italy; and Assunta \\ Bertaccini, UCI-STAA Patologia Vegetale, University of Bologna, 40126, Bologna Italy
}

\begin{abstract}
Martini, M., Murari, E., Mori, N., and Bertaccini, A. 1999. Identification and epidemic distribution of two flavescence dorée-related phytoplasmas in Veneto (Italy). Plant Dis. 83:925-930.

Grapevine yellows associated with phytoplasmas of the elm yellows group (16SrV), better known as flavescence dorée (FD), is a serious quarantine problem in some important grapevine growing regions in the European Union. A survey was carried out in 1997 to 1998 in Veneto region (Italy) where a serious outbreak of FD was in progress. Phytoplasma identification by nested polymerase chain reaction (PCR)/restriction fragment length polymorphism (RFLP) analyses on 275 grapevine samples and on batches of Scaphoideus titanus was carried out. RFLP analyses of the 16S rDNA/spacer region with TaqI detected the presence of two distinct elm yellows phytoplasma subgroups designated $16 \mathrm{SrV}-\mathrm{C}$ and $16 \mathrm{SrV}-\mathrm{D}$ in 77 FD-infected grapevine samples. Only phytoplasmas of the 16SrV-D subgroup were detected in S. titanus. In 1997, the two phytoplasma subgroups appeared to be located in two diverse geographic areas; but in 1998 , the $16 \mathrm{SrV}-\mathrm{D}$ type also was detected in the provinces where in 1997 only $16 \mathrm{SrV}-\mathrm{C}$ type was identified. The sequencing of a 400-bp fragment at the $3^{\prime}$ end of 16S rDNA plus spacer region allowed a specific primer construction that was successfully employed for detection of both FD types in grapevine by direct PCR.
\end{abstract}

Grapevine yellows diseases occur in various regions of the world. They exhibit nearly identical symptoms but are believed to be caused by molecularly distinguishable phytoplasmas $(3,8,12,14,17,24,29)$. Among grapevine yellows diseases, the flavescence dorée (FD) was the first one described in France (11) and, with "Bois Noir" (BN, or in Germany, "Vergilbunskrankheit," VK), is one of the most important yellows diseases for quarantine purposes. FD is transmitted by the nearctic leafhopper Scaphoideus titanus.

The etiological agents of grapevine yellows diseases have been attributed to phytoplasmas of different $16 \mathrm{~S}$ rRNA restriction fragment length polymorphism (RFLP) groups, namely 16SrI (aster yellows and related strains), 16SrIII (X-disease and related strains), $16 \mathrm{SrV}$ (elm yellows and related strains), and $16 \mathrm{SrXII}$ (stolbur and related strains) $(22,33)$.

In Italy, preliminary molecular identification tests showed phytoplasmas belonging to $16 \mathrm{~S}$ rDNA groups XII-A (stolbur and related strains) and $\mathrm{V}$ (elm yellows and related strains) were associated, respectively, with $\mathrm{BN}$ and $\mathrm{FD}$, and frequently

Corresponding author: Assunta Bertaccini E-mail: Bertaccini_A@biblio.cib.unibo.it

Accepted for publication 16 June 1999.

Publication no. D-1999-0722-01R

(C) 1999 The American Phytopathological Society occurred in mixed infections $(7,9)$. More recently, a strong epidemic of FD was reported in the Veneto region $(4,5,28,30)$ that continued to spread in spite of efforts to control S. titanus. Over the past 3 years, molecular detection tests were utilized to assure that propagative cuttings were not taken from FD-infected vineyards. Since recent reports showed the presence of FD phytoplasmas diverse for chromosomal $(10,13)$ and in one case for ribosomal sequences (25), a verification of FD phytoplasmas identity was performed using nested polymerase chain reaction (PCR)/ RFLP analyses on 16Sr DNA/spacer region. Sequencing of some of the FD strains was also performed on a portion of this region, and primers for specific direct PCR were designed. A short account of part of this research was presented elsewhere (26).

\section{MATERIALS AND METHODS}

Grapevine and insect samples. Samples belonging to about 40 diverse grapevine cultivars were collected in Veneto vineyards during 1997 and 1998. A total of 275 samples from five different provinces of Veneto (Verona, Treviso, Vicenza, Venezia, and Padova) were collected.

Batches containing 1 to $10 \mathrm{~S}$. titanus collected in vineyards located in Verona, Vicenza, Padova, and Treviso provinces were also obtained.

Reference phytoplasma strains. Control samples used in PCR/RFLP analyses for group $16 \mathrm{SrV}$ phytoplasmas in naturally infected plants were rubus infected with stunt disease (20), eucalyptus little leaf, hornbeam with witches'-broom collected in diverse regions of central and south Italy (26), and grapevine FD strain B1872 (kindly provided by E. Boudon-Padieu, INRA, Dijon, France). Further reference phytoplasma strains (in periwinkle) used to represent the majority of phytoplasma groups reported in the literature were: North American aster yellows from tomato and Maryland aster yellows (BB and AY-1; I.-M. Lee, USDA, Beltsville, MD); clover phyllody $(\mathrm{CPh}$; L. N. Chiykowski, Agriculture Canada, Ottawa, Ontario, Canada [via I.-M. Lee]) for the subgroups 16SrI-A, 16 SrI-B, and 16SrI-C respectively; Italian periwinkle virescence (IPVR) for the group 16SrXII-A (formerly subgroup 16SrI-G); peach X disease for the 16SrIII-A (CX; B. C. Kirkpatrick, University of California, Davis, [via I.-M. Lee]); ash yellows for the 16SrVII-A (ASHY; W. A. Sinclair, Cornell University, Ithaca, NY [via E. Seemüller]); Australian tomato big bud for 16SrII (TBB; M. F. Clark, HRI, East Malling, Kent, UK [via E. Seemüller]); beet leafhopper transmitted virescence for $16 \mathrm{SrVI}$ (BLTVA; D. Golino, University of California, Davis, [via E. Seemüller]); apple proliferation for the 16SrX-A (AP; L. Carraro, University of Udine; Italy); annual blue grass white leaf for 16SrXIV-A (ABGWL) (23); elm yellows (EY; H. Griffith and W. A. Sinclair, Cornell University, Ithaca, NY); and elm witches'-broom (ULW; E. Seemüller, BBA, Dosseheim, Germany) for $16 \mathrm{SrV}-\mathrm{A}$ group.

Phytoplasma detection. Total nucleic acids were extracted from about $1 \mathrm{~g}$ of fresh plant tissue (leaf midribs) ground in liquid nitrogen. The DNA extraction protocol employed has already been described by Prince et al. (29).

Plant nucleic acid was diluted in sterile deionized water to a final concentration of $20 \mathrm{ng} / \mu \mathrm{l}$, and $1 \mu \mathrm{l}$ of this solution was used for PCR assays.

Following a modified DNA extraction procedure previously described (34), $S$. titanus adults were ground in Eppendorf tubes with $200 \mu \mathrm{l}$ of sterile CTAB buffer (2\% wt/vol CTAB, $1.4 \mathrm{M} \mathrm{NaCl}, 0.2 \%$ [vol/vol] 2-mercaptoethanol, $20 \mathrm{mM}$ EDTA, $100 \mathrm{mM}$ Tris-HCl, pH 8.0). The suspension was then incubated $20 \mathrm{~min}$ at $60^{\circ} \mathrm{C}$ and mixed at regular intervals. An equal volume of chloroform-octanol was added to the suspension, mixed carefully, 
and centrifuged $8 \mathrm{~min}$ at $14,000 \mathrm{rpm}$. After precipitation with cold isopropanol and centrifugation for $30 \mathrm{~min}$ at $14,000 \mathrm{rpm}$, the pellet was washed with $70 \%$ ethanol, centrifuged, and suspended in TE buffer (10 mM Tris-HCl, 1 mM EDTA, $\mathrm{pH}$ 8.0). One microliter of sterile-water-diluted supernatant (1:50) was used in PCR assays.

Total DNAs extracted were processed with nested PCR using two phytoplasma universal primer pairs, R16F1/R0 (1,400 bp) and R16F2n/R2 (1,200 bp) (19).
Each reaction was performed in a total volume of $25 \mu \mathrm{l}$ containing $2.5 \mu \mathrm{l}$ of the $10 \times$ buffer (31), $200 \mu \mathrm{M}$ of dNTP, $0.625 \mathrm{U}$ of Taq polymerase (Roche, Branchburg, $\mathrm{NY}$ ), and $0.4 \mu \mathrm{M}$ of primer pair. Tubes with water instead of the template DNA were included in each reaction series as negative PCR controls.

The PCR conditions for all the abovelisted primers were 35 cycles in a PerkinElmer Cetus thermal cycler: each cycle was of $1 \mathrm{~min}$ ( $2 \mathrm{~min}$ for the first cycle) denaturation step at $94^{\circ} \mathrm{C}, 2 \mathrm{~min}$ for annealing at $50^{\circ} \mathrm{C}$, and $3 \mathrm{~min}(10 \mathrm{~min}$ for the last cycle) at $72^{\circ} \mathrm{C}$ for primer extension. Six microliters of each sample were subjected to electrophoresis in a $1 \%$ agarose gel and visualized by staining with ethidium bromide and UV illumination.

Eight microliters of the PCR products amplified by using the R16F2n/R2 were digested with $2 \mathrm{U}$ of $\mathrm{MseI}$ (New England Biolabs, Beverly, MA) following the instruction of the manufacturer to identify

\begin{abstract}
1264
FD 5'-CAACTCGACT TCATGAAGCT GGAATCGCTA GTAATCGCGA CACCGCCCGT CAAACCACGA AAGTTAGCAA TACCCG--AAAG Co 5'-CAANTNGANT TCATGAAGCT GGAATCGNTA GTAATCGCGA ATCAGCATGT CGCGGTGAAT ACGTTCTCGG GGTTTGTACA---

Pe 5

RS 5

Rus 5'CAACTCGA|CT TCATGAAGCT GGAATCGCTA GTAATCGCGA ATCAGCATGT CGCGGTGAAT ACGTTCTCGG GGTTTGTACAEY 5'-CAACTCGA CT TCATGAAGCT GGAATCGCTA GTAATCGCGA ATCAGCATGT CGCGGTGAAT ACGTTCTCGG GGTTTGTACA1344

FD CACCGCCCGT CAAACCACGA AAGTTAGCAA TACCCG-AAAG CAGTGGCTTA ACTTCGGAAG AAGAGGGAGC TGTCTAAGGT Co CACCGCCCGT CAAACCACGA AAGTTAGCAA TACCCG--AAAG CAGTGGCTTA ACT TCGAAAG AAGAGGGAGC TGTCTAAGGT

$\mathrm{Ga}$

$\mathrm{Pe} \quad \mathrm{PSC}$

RS CACCGCCCGT CAAACCACGN AAGTNAGCAA TACCCGGAAAG CAGGGGCTTA ANTTNGGANG AAGAGGGAGC NGTNTAAGGT RuS CACCGCCCGT CAAACCACGA AAGTTAGCAA TACCCG-AAAG CAGTGGCTTA ACTT[]GGAAG AAGAGGGAGC TGTCTAAGGT EY CACCGCCCGT CAAACCACGA AAGTTAGCAA TACCCG--ANAG CAGTGGCTTA ACTTCGCAAG AAGAGGGAGC TGTCTAAGGT 1425

FD AGGGTTGATG ATTGGGgtTA AGTCGTAACA AGGTATCCTT ACCGGAAGGT GAGGAT--GGAT CACCTCC--TTT CTAAGGACAT Co AGGGTTGATG ATTGGGGTTA AGTCGTAACA AGGTATCCTT ACCGGAAGGT GAGGAT--GGAT CACCTCC--TTT CTAAGGACAT Ga - - - CNTT NCCG-AAAGT GAGGATNNGAT CACCTC---TTT CTAAGGACAT $\mathrm{Pe}$ - - AGONATCCTG ACCNGAAGGT GAGGAG-NNAT CACCTCTNTTT GTAAGGACAT RS AGGGTTGANG ATTGGGGTNA AGTCGTNACA AGGTATCCTT ACCGGAAGGT GAGGAT--GGAT CACCTCCNTTT CTAAGGACAT RuS AGGGTTGATG ATTGGGGTTA AGTCGTAACA AGGTATCCTT ACCGGAAGGT GAGGAT--GGAT CACCTCC--TTT CTAAGGACAT EY AGGGTTGATG ATTGGGGTTA AGTCGTAACA AGGTATCCTT ACCGGNNGGT GAGGAT--GGAT CACCTCC--TTT CTAAGGACAT

1507

FD ACATAT-NAAA ATCATCATCT TCAGTTTTGA AAGACTTAGG TTAAAATATA AGTTTTTCTT TTTATAAANAA AAGTGTTTCT Co ACATAT--AAAA ATCATCATCT TCAGTTTTGA AAGACTTAGG TTAAAATATA AGTTTTTCTT TTTATAAA--AA AAGTGTTTCT Ga ACATAT-AAAA ATCATCATCT TCAGTTTTGA AAGACTTAGG TTAAAATATA AGTTTTTCTT TTTATAAA--AA AAGTGTTTCT Pe ACATATGGCAA ATCATCATNT TCNGTNNTGA AAGACNTAGG TTAAAATATA AGTTTTTCTT TTTATAAAAAA AAGTGTTTCT RS ACATAT--AAAA ATCATCATCT TCAGTTTTGA AAGACNTAGG TTAAAATATA AGTTTTTCTT TTTATAAA--AA AAGTGTTTCT RuS ACATAT- AAAA ATCATCATCT TCAGTTTTGA AAGACTTAGG TTAAAATATA AGTTTTTCTT TTTATAAA-AA AAGTGTTTCT EY --CATATTAAAA ATI ATCATCT TCAGTTTTGA AAGACTTAGg TTAAAATATA AGTTTTTCTT TTTACAAAAAA AAGTGTTTCT 1589

FD CTTATATNAA AGACCAA-- --AGG GCCTATAGCT CAGTTGGTTA GAGCACACGC CTGATAAGCG TGAGGT--CGGT GGTTCAAGTC Co CTTATATAAA AGACCAA - --AGG GCCTATAGCT CAGTTGGTTA GAGCACACGC CTGATAAGCG TGAGGT--CGGT GGTTCAAGTC $\mathrm{Ga}$ CTTATATAAA AGACCAA- ---AGG GCCTATAGCT CAGTTGGTTA GAGCACACGC CTGATAAGCG TCAGG CACGGT GGTTCAAGTC Pe CTTATATAAA AGACCAA- --AGG GCCTATAGCT CAGTTGGTTA GAGCACACGC CTGATAAGCG TGAGGT--CGGT GGTTCAAGTC RS CTTATATAAA AGACCAACO AGG GCCTATAGCT CAGTTGGTTA GAGCACACGC CTGATAAGCG TGAGGT--CGGT GGTTCAAGTC RuS CTTATATAAA AGACCAA AGg GCCTATAGCT CAGTTGGTTA GAGCACACGC CTGATAAGCG TGAGGT--CGGT GGTTCAAGTC EY CTTATATAAA AGACCAA-- A GG GCCTATAGCT CAGTTGGTTA GAGCACACGC CTGATAAGCG TGAGGT-CGGT GGTTCAAGTC 1672

FD CACTTAGGCC C-ACC--AATTTT ATATCAGGAA AATATTTACT----TCGAAGAAAG TT-CTTT GAA AAGTAGATAA ACATGA TT

Co CACTTAGGCC C-ACC--AATTTT ATATCAGGAA AATATTTACT--- TCGA AGAAAG TTTCTTTGAA AAGTAGATAA ACATGA TT

$\mathrm{Ga}$ CACTTAGGCC CDACCDAATTTT ATATCAGGAA AATATTTACT--- TCGA AGAAAG TT-CTTT GAA AAGTAGATAA ACA-GA TN

Pe CACTTAGGCC C-ACC--A ATTTT ATATCAGGAA AATATTTACT----TCGA AGAAAG TTNCTTT GAN AANTAGATAA ACATGANN

RS CACTTAGGCC C-ACC--A ANCCO NTATCAGGAA NANATTTACT--- TCGAAGNAAG TTNNTTNGGA NAGTAGATAT ACATGA TT

RuS CACTTAGGCC C-ACC-AATTTT- ATATCAGGAA AATATTTACT---TCGAAGAAAG TT-CTTT GAA AAGTAGATAA ACATGACGTT EY CACTTAGGCC C-ACC--AATTTT ATATCAGGAA AATATTTACT ACTTTGAAGAAA
\end{abstract}

Fig. 1. Alignment of the phytoplasma sequences from three grapevine flavescence dorée (FD) infected and the rubus stunt (RS) control with FD, rubus stunt in periwinkle (RuS), and elm yellows (EY) strains from GenBank (accession numbers, respectively, X76560, Y16395, and L33763). Boxes indicate differences in sequences; primer V1731 is underlined. Co, grapevine cv. Corvina; Ga, grapevine cv. Garganega; Pe, grapevine cv. Perera. 
phytoplasmas. The RFLP fragments were visualized by electrophoresis in a $5 \%$ polyacrylamide gel in $1 \times$ TBE buffer $(0.09 \mathrm{M}$ Tris-borate, $0.002 \mathrm{M}$ EDTA) followed by staining with ethidium bromide and visualization under a UV transilluminator.

Differentiation of phytoplasmas associated with FD. FD phytoplasma identification was preliminarily carried out with group V specific primers R16(V)F1/R1 (1,100 bp) (21). On samples positive for EY-type phytoplasmas, a new nested PCR procedure was adopted using primers $16 \mathrm{R}_{723 \mathrm{f}} / \mathrm{P} 7(1,100 \mathrm{bp})(27,32)$ followed by primers $\quad 1_{758} / \mathrm{M}^{2} 3 \mathrm{SR}_{1804 \mathrm{r}} \quad(1,050 \mathrm{bp})$ $(18,27)$ in order to amplify the $3^{\prime}$ end of the $16 \mathrm{~S}$ region and most of the spacer region.

The PCR products amplified by using the specific primers R16(V)F1/R1 were digested overnight $(16 \mathrm{~h})$ at $37^{\circ} \mathrm{C}$ with $B f a$ I. Further RFLP of amplified products

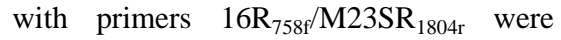
carried out with $T a q \mathrm{I}$ and incubated overnight at $65^{\circ} \mathrm{C}$. The digestions were performed in buffers supplied by the manufacturer (New England Biolabs) according to instructions.

Further direct PCR analyses were carried out on selected FD-infected samples using nonribosomal primers FD9f/r in the conditions described by Daire et al. (13), followed by RFLP with $M s e \mathrm{I}$ and $A l u \mathrm{I}$. Primers $16 \mathrm{R}_{758 \mathrm{f}} / \mathrm{V}_{1731 \mathrm{r}}$ (see below) were then employed for direct detection and classification of FD phytoplasmas in grapevine.

Sequencing and primer construction. Amplified PCR products with primers

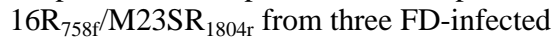
grapevine cultivars (Corvina and Garganega from Verona and Perera from Treviso province [6]) plus a rubus stunt strain (20) (Fig. 1) were sequenced in the $3^{\prime}$ end of $16 \mathrm{~S}$ rDNA and in the $16 \mathrm{Sr}-23 \mathrm{~S}$ spacer region (from base 1,264 to base 1,754) in order to study variability for specific primer design.

The sequencing was performed in an “ABI Prism DNA sequencing” Model 377 (PE Applied Biosystem, Foster City, CA) using primer P3 (32) and dichlororhodamine dye terminators. After sequencing, a primer was designed $\left(\mathrm{V}_{1731 \mathrm{r}}\right)$ (Fig. 1) and tested in seminested PCR with primer $16 \mathrm{R}_{758 \mathrm{f}}$ after a first PCR run with primers $16 R_{758} / M_{23 S R} R_{1804 r}$ on all the control samples described above for specificity.

\section{RESULTS}

Phytoplasma detection. Nested PCR using universal primers followed by RFLP analyses detected the presence of phytoplasmas in 165 grapevine samples: 77 were infected by a phytoplasma of the EY group after PCR with specific primers R16(V)F1/ R1 and/or RFLP analyses with MseI. The EY-infected plants were distributed in all the provinces examined and on different grapevine cultivars with the highest percentage of infected plants in Verona prov- ince (Table 1). The other positive samples were infected by a BN-type (16SrXII-A) phytoplasma or in some cases by $16 \mathrm{SrI}-\mathrm{B}$ or 16SrI-C type phytoplasmas (Fig. 2).

Differentiation of phytoplasmas associated with FD. Further RFLP analyses with $B f a I$ on R16(V)F1/R1-amplified products allow the distinction of FD- from EYinfected samples: none of the grapevines were infected by $16 \mathrm{SrV}$-A type of phytoplasmas (EY) (Fig. 3A).

Similar analyses on $16 \mathrm{R}_{758} / \mathrm{M} 3 \mathrm{SR}_{1804 \mathrm{r}^{-}}$ amplified products with TaqI showed the presence of two diverse FD types of phytoplasmas in the grapevines (Fig. 3C). The samples of $S$ titanus tested showed the presence of FD phytoplasmas $(16 \mathrm{SrV}$ group) when collected in Verona and Vicenza provinces, and no phytoplasma presence when collected in Treviso and Padova areas (Fig. 3B). In some of the samples from Verona, a BN-type phytoplasma (16SrXII-A group) also was present (Fig. 3C). The two subgroups detected were designated $16 \mathrm{SrV}-\mathrm{C}$ and $16 \mathrm{SrV}-\mathrm{D}$, respectively, and $S$. titanus

Table 1. Distribution of the two phytoplasma flavescence dorée (FD) types identified in three provinces of the Veneto region during 1997 and 1998 (tests were carried out on selected samples)

\begin{tabular}{|c|c|c|c|c|}
\hline Geographic locations & Cultivars & 1997 & 1998 & Phytoplasmas \\
\hline \multicolumn{5}{|l|}{ Verona (VR) } \\
\hline 1. Affi & Pinot grigio & & September & 16SrV-D \\
\hline 2. Affi & Sangiovese & & September & 16SrV-D \\
\hline 3. Affi & Chardonnay & & September & 16SrV-D \\
\hline 4. Bardolino & Ribolla & & October & 16SrV-D \\
\hline 5. Bussolengo & Marzemino & & September & 16SrV-D \\
\hline 6. Calmasino & Corvina & & October & 16SrV-D \\
\hline 7. Castelnuovo & Trebbiano & June & & 16SrV-D \\
\hline 8. Cavaion & Trebbiano Toscano & & September & 16SrV-D \\
\hline 9. Cavaion & Corvina & & October & 16SrV-D \\
\hline 10. Cavaion & Corvina & & October & 16SrV-D \\
\hline 11. Costermano & Garganega & & September & 16SrV-D \\
\hline 12. Lazise & Chardonnay & June & & 16SrV-D \\
\hline 13. Lazise & Chardonnay & June & & 16SrV-D \\
\hline 14. Lazise & Trebbiano & June & & 16SrV-D \\
\hline 15. Lazise & Garganega & June & & 16SrV-D \\
\hline 16. Lazise & Corvina & & October & 16SrV-D \\
\hline 17. Negrar & Corvinone & & October & 16SrV-D \\
\hline 18. Negrar & Croatina & & October & 16SrV-D \\
\hline 19. Peschiera & Trebbiano & & October & 16SrV-D \\
\hline \multicolumn{5}{|l|}{ Treviso (TV) } \\
\hline 1. Caerano & Cabernet & June & & $16 \mathrm{SrV}-\mathrm{C}$ \\
\hline 2. Castelcucco & Prosecco & June & & $16 \mathrm{SrV}-\mathrm{C}$ \\
\hline 3. Castello di Godego & Cabernet-Sauvignon & June & & $16 \mathrm{SrV}-\mathrm{C}$ \\
\hline 4. Cimadolmo & Chardonnay & July & & $16 \mathrm{SrV}-\mathrm{C}$ \\
\hline 5. Cordignano & Cabernet-Sauvignon & & September & $16 \mathrm{SrV}-\mathrm{C}$ \\
\hline 6. Fontanelle & Prosecco & & September & $16 \mathrm{SrV}-\mathrm{C}$ \\
\hline 7. Fontanelle & Cabernet & & September & $16 \mathrm{SrV}-\mathrm{C}$ \\
\hline 8. Maser & Chardonnay & June & & $16 \mathrm{SrV}-\mathrm{C}$ \\
\hline 9. Mussolente & Unknown hybrid & & October & 16SrV-D \\
\hline 10. Povegliano & Cabernet-Sauvignon & June & & $16 \mathrm{SrV}-\mathrm{C}$ \\
\hline 11. Preganziol & Verduzzo & & September & 16SrV-D \\
\hline 12. San Fior & Merlot & July & & $16 \mathrm{SrV}-\mathrm{C}$ \\
\hline 13. San Pietro di F. & Marzemino & & September & $16 \mathrm{SrV}-\mathrm{C}$ \\
\hline 14. Spresiano & Chardonnay & & September & $16 \mathrm{SrV}-\mathrm{C}$ \\
\hline 15. Spresiano & Cabernet-Sauvignon & & September & $16 \mathrm{SrV}-\mathrm{C}$ \\
\hline 16. Spresiano & Prosecco & February & & $16 \mathrm{SrV}-\mathrm{C}$ \\
\hline 17. Spresiano & Corvina & February & & $16 \mathrm{SrV}-\mathrm{C}$ \\
\hline 18. Spresiano & Chardonnay & February & & $16 \mathrm{SrV}-\mathrm{C}$ \\
\hline 19. Susegana & Perera & & September & $16 \mathrm{SrV}-\mathrm{C}$ \\
\hline 20. Susegana & Prosecco & & September & 16SrV-D \\
\hline 21. Susegana & Bianco Manzoni & & September & $16 \mathrm{SrV}-\mathrm{C}$ \\
\hline 22. Susegana & Bianco Manzoni & & September & 16SrV-D \\
\hline 23. Volpago & Riesling & June & & $16 \mathrm{SrV}-\mathrm{C}$ \\
\hline \multicolumn{5}{|l|}{ Vicenza (VI) } \\
\hline 1. Breganze & Marzemino & & October & 16SrV-D \\
\hline 2. Gambellara & Garganega & September & & 16SrV-D \\
\hline 3. Rosà & Unknown hybrid & & October & 16SrV-D \\
\hline 4. San Giorgio & Malvasia & & October & 16SrV-D \\
\hline 5. San Giorgio & Malvasia & & October & 16SrV-D \\
\hline 6. Sarcedo & Pinot grigio & & October & 16SrV-D \\
\hline \multicolumn{5}{|l|}{ Padova (PD) } \\
\hline 1. Dossi Terrassa & Trebbiano Toscano & & September & 16SrV-D \\
\hline 2. Torreglia & Merlot & & September & 16SrV-D \\
\hline 3. Torreglia & Cabernet-Sauvignon & & October & 16SrV-D \\
\hline 4. Villa di Teolo & Bianco Manzoni & & September & 16SrV-D \\
\hline 5. Villa di Teolo & Merlot & & September & $16 \mathrm{SrV}-\mathrm{D}$ \\
\hline
\end{tabular}


only contained $16 \mathrm{SrV}$-D type phytoplasmas.

The existence of these two FD subgroups also was confirmed by RFLP on DNA fragments amplified with chromosomal primers FD9f/r. The control FD strain (B1872) had an identical pattern after restriction digest with $M s e \mathrm{I}$ and $A l u \mathrm{I}$ to the samples containing $16 \mathrm{SrV}-\mathrm{D}$ type phytoplasmas, and these were distinguishable from those containing the $16 \mathrm{SrV}-\mathrm{C}$ type phytoplasmas as well (Fig. 4).

The manual alignment of $400 \mathrm{bp}$ from Corvina, Garganega, Perera, and Rubus with EY, RuS (a rubus stunt isolate in periwinkle), and FD strain sequences from GenBank showed that there is a differential restriction site for $T a q \mathrm{I}$ in Corvina located in position 1,398 in the $16 \mathrm{~S}$ ribosomal sequence (Fig. 1). The alignment shows a high degree of conservation in sequences at the $5^{\prime}$ end of the spacer region, where a reverse primer of 20 bases specific for the studied strains was designed (Fig. 1).

The comparative tests carried out in seminested PCR with primer $\mathrm{V}_{1731 \mathrm{r}}$ show the specificity of the system for $16 \mathrm{SrV}$ group phytoplasmas (Fig. 5A to $\mathrm{C}$ ). More

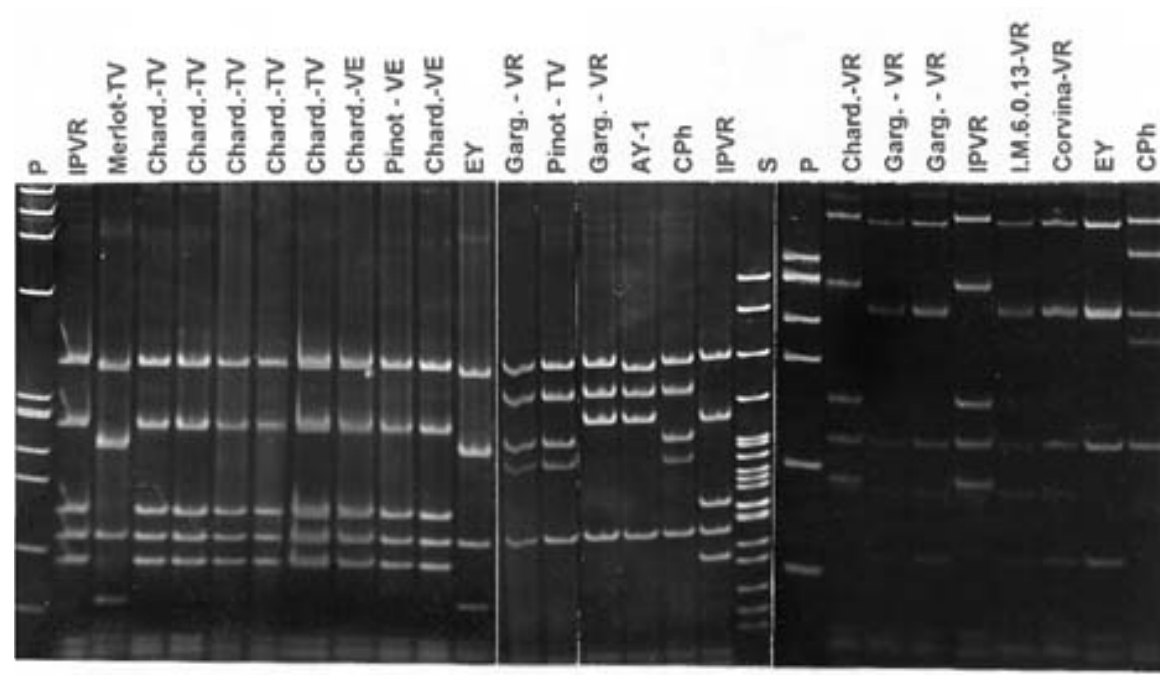

Fig. 2. Polyacrylamide gels (5\%) showing the MseI restriction fragment length polymorphism (RFLP) patterns of phytoplasma 16SrDNA fragments of 1,200 bp obtained with primers R16F2n/R2 from grapevine samples and from phytoplasma reference strains. Aster yellows, AY-1; clover phyllody, $\mathrm{CPh}$; Italian periwinkle virescence, IPVR; Elm yellows, EY. Grapevine samples are indicated following Table 1 or by cultivar name. VR, Verona; TV, Treviso; VE, Venezia; VI, Vicenza; and PD, Padova. P, marker $\phi X 174$ HaeIII digested; fragment sizes in base pairs from top to bottom: 1,353, $1,078,872,603,310,281,271,234,194,118$, and 72. S, marker pBR322 MspI digested; fragment sizes in base pairs from top to bottom: $622,527,404,307,242,238,217,201,190,180,160,147$, $123,110,90,76,67,34,26,15,9$. specificity tests carried out with controls from the other $16 \mathrm{~S}$ rRNA phytoplasma groups listed in Materials and Methods confirm this results (data not shown). The RFLP analyses with TaqI confirmed the suitability of the system to distinguish the two FD types present in the material examined (Fig. 5D). The subgroup $16 \mathrm{SrV}-\mathrm{C}$ is not discriminated from subgroup $16 \mathrm{SrV}$ $\mathrm{A}$, since the reverse primer contains the restriction site for TaqI located in position 1,714 of the spacer region. Direct PCR with primers $16 \mathrm{R}_{758 \mathrm{f}} / \mathrm{V}_{1731 \mathrm{r}}$ allowed the detection of FD phytoplasma from infected plants (Fig. 6).

From the epidemiological survey in 1997, it appears that the two types of FD phytoplasmas were distributed in geographically distinct provinces (i.e., $16 \mathrm{SrV}$ $\mathrm{D}$ in Verona and Vicenza and 16SrV-C in Treviso). In 1998, the $16 \mathrm{SrV}-\mathrm{D}$ phytoplasmas were present also in samples from Treviso province, sometimes in the same localities; in one case, the same cultivar showed plants infected with one or the other type of phytoplasma, i.e., Bianco Manzoni located at Susegana (Table 1).

\section{DISCUSSION}

The tests carried out in different periods of the year (Table 1) on different grapevine tissues showed that phytoplasma detection was possible in vegetative and in dormant materials (i.e., leaf midribs or phloem from canes and trunk).

Two molecularly diverse phytoplasmas related to FD were present in the Veneto region, but only one of the two types appeared to spread. A survey on the geographical location of these strains in the 2year period indicated a rapid diffusion of the $16 \mathrm{SrV}-\mathrm{D}$ type in areas around the original epidemic center (Verona), al-

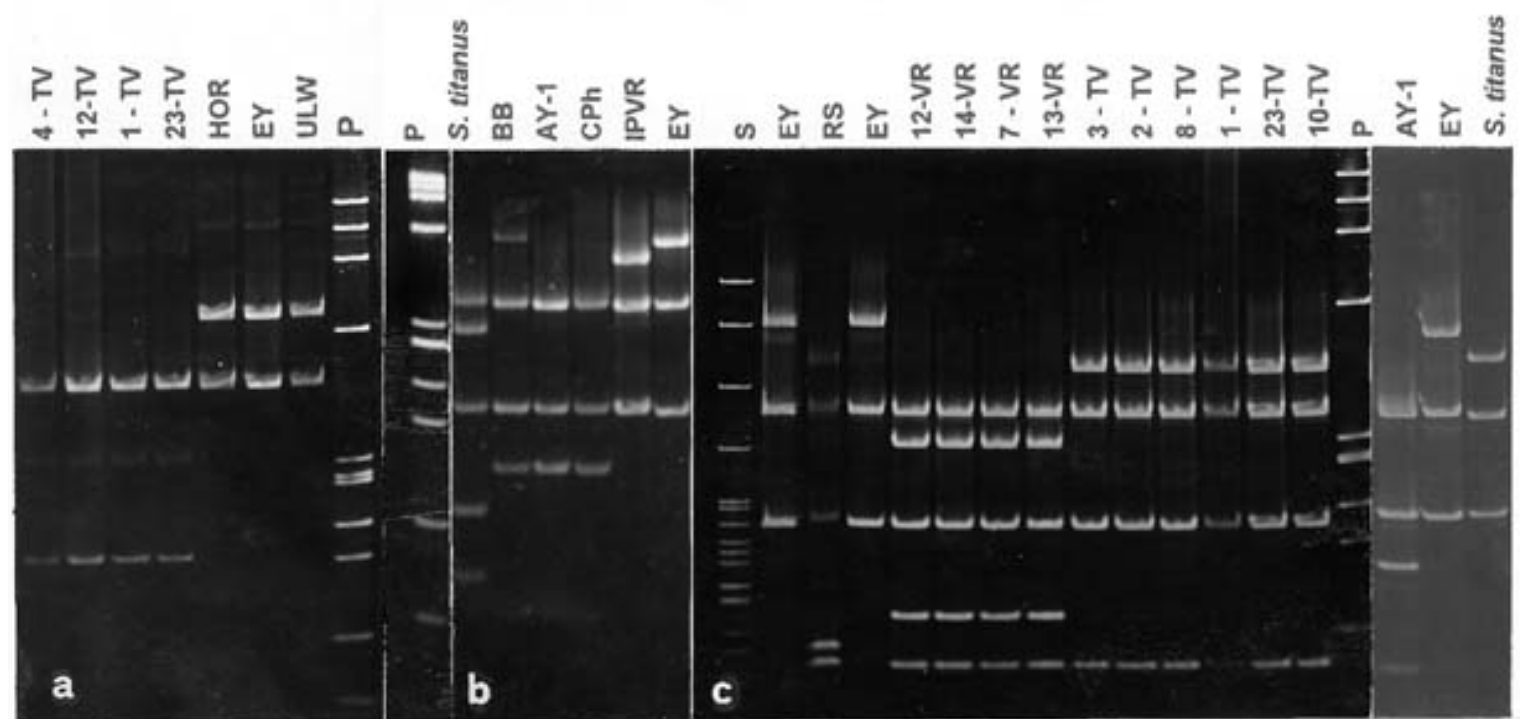

Fig. 3. Polyacrylamide gels (5\%) showing (A) $B f a \mathrm{I}$ restriction fragment length polymorphism (RFLP) patterns of phytoplasma $16 \mathrm{~S}$ rDNA fragments of 1,100 bp obtained with primers R16(V)F1/R1 and (B) TaqI RFLP patterns of 1,050-bp fragments obtained with primers 16R758f/M23SR1804. EY, elm yellows (USA); ULW, elm yellows (EU); HOR, hornbeam; RS, rubus stunt; BB, North American aster yellows from tomato; AY-1, aster yellows; CPh, clover phyllody; IPVR, Italian periwinkle virescence. VR, Verona; TV, Treviso. Grapevine samples are indicated following numbers in Table 1. P, marker $\phi X 174$ HaeIII digested; S, marker pBR322 MspI digested. 
though treatments to contain $S$. titanus were applied by growers.

$16 \mathrm{SrV}-\mathrm{D}$ was the only phytoplasma associated with FD detected in S. titanus; some leafhoppers appeared to carry $\mathrm{BN}$ phytoplasmas, but no involvement of this vector in the spread of $\mathrm{BN}$ was reported. However, phytoplasmas of this group

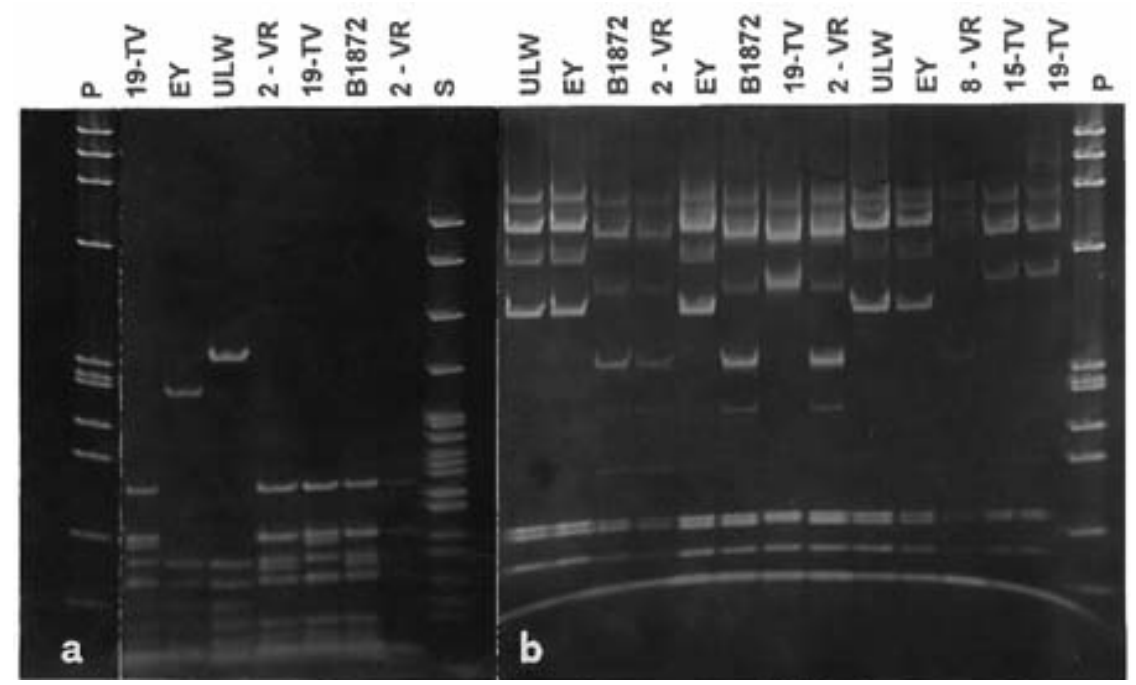

Fig. 4. Polyacrylamide gels (5\%) showing the restriction fragment length polymorphism (RFLP) patterns of phytoplasma chromosomal fragments amplified with primers FD9f/r from grapevine samples and from reference strain B1872 using MseI (A) and $A l u I$ (B) enzymes. EY, elm yellows (USA); ULW, elm yellows (EU); VR, Verona; TV, Treviso. Grapevine samples are indicated following numbers in Table 1. P, marker $\phi$ X174 HaeIII digested; S, marker pBR322 MspI digested.

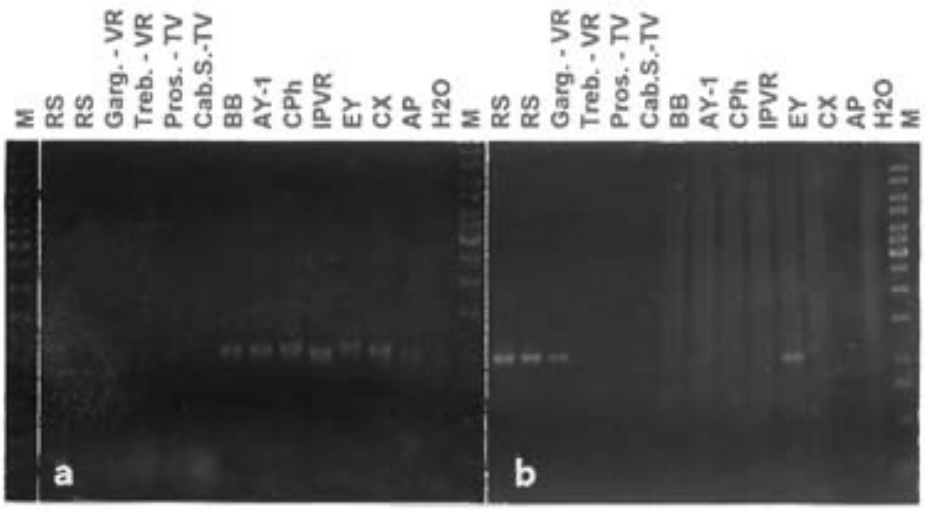

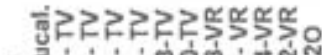

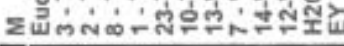

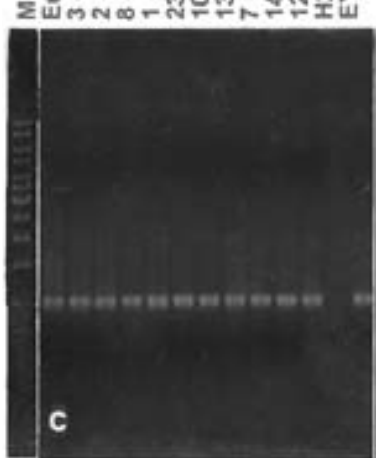

$\infty$

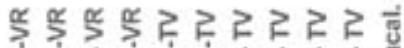
q

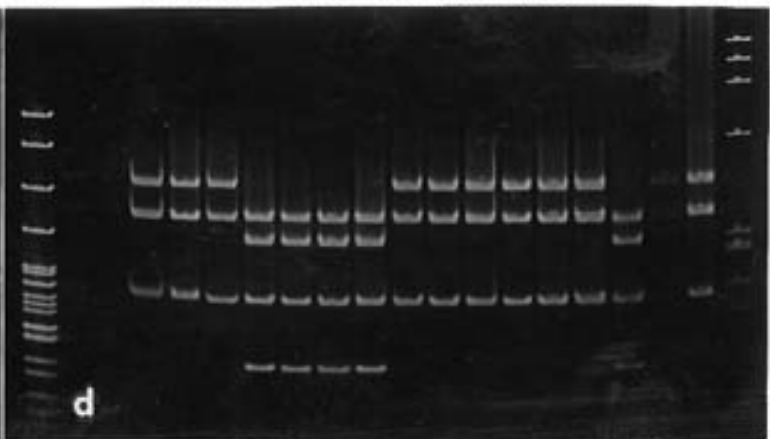

Fig. 5. Agarose gel electrophoresis photographs of polymerase chain reaction (PCR) products of phytoplasma DNA amplified with primers 16R723f/P7 in direct PCR (A) and in nested PCR with primers 16R758f/V1731r in (B) and in (C). CX, peach X disease; AP, apple proliferation; EY, elm yellows; RS, rubus stunt; BB, North American aster yellows from tomato; $\mathrm{AY}-1$, aster yellows; $\mathrm{CPh}$, clover phyllody; IPVR, Italian periwinkle virescence. VR, Verona; TV, Treviso. Grapevine samples are indicated following numbers in Table 1 or by cultivar name. P, marker $\phi X 174$ HaeIII digested; S, marker pBR322 MspI digested; M, marker 1-kb DNA ladder; fragment sizes in kilobase pairs from top to bottom: 10.0, 8.0, 6.0, 5.0, 4.0, 3.5, 3.0, 2.5, 2.0, 1.5, 1.0, 0.5. (D) restriction fragment length polymorphism (RFLP) analyses with TaqI of the PCR products in (C).

(stolbur or $16 \mathrm{SrXII-A}$ ex $16 \mathrm{SrI}-\mathrm{G}$ ) were detected in eggs of $S$. titanus, together with other aster yellows-related phytoplasmas $(2,15)$.

The differences demonstrated in the $16 \mathrm{~S}$ ribosomal DNA region of FD-related phytoplasmas allowed the establishment of a new $16 \mathrm{SrV}$ subgroup; these data were also in agreement with the presence in France of two FD-type phytoplasmas identified by RFLP on randomly cloned FD chromosomal DNA (13).

RFLP with $A l u \mathrm{I}$ on products amplified with primers FD9f/r phytoplasmas showed a $16 \mathrm{SrV}-\mathrm{D}$ pattern indistinguishable from the one of B1872 (French FD control) and also from pattern FD88 described by Daire et al. (13); strain $16 \mathrm{SrV}-\mathrm{C}$ appeared to be identical to FD70 (13); patterns with MseI showed identity between 16SrV-D and $\mathrm{B} 1872$ and differentiated them from 16SrV-C.

Among the samples employed as $16 \mathrm{SrV}$ group controls from naturally infected plants, the rubus stunt strain employed was tentatively assigned to the $16 \mathrm{SrV}-\mathrm{C}$ subgroup (22) in agreement with the literature. The TaqI difference from the $16 \mathrm{SrV}-\mathrm{C}$ subgroup observed on $16 \mathrm{R}_{758 \mathrm{f}} / \mathrm{M}_{23} \mathrm{SR}_{1804 \mathrm{r}}$ amplified sequence was not supported by the partial sequence carried out. The hornbeam strain was enclosed in the $16 \mathrm{SrV}-\mathrm{A}$ subgroup, while the examined strain of eucalyptus little leaf from southern Italy appeared to belong to subgroup $16 \mathrm{SrV}-\mathrm{D}$. The latter was the first report of 16SrV-D group phytoplasmas in a host different from grapevine in southern Italy, where only yellows-related phytoplasmas were reported in this host $(1,16)$.

The detection system developed will facilitate FD-related phytoplasma detection: direct PCR on the ribosomal region for routine testing associated with TaqI distinction of the two FD-strains increases possibilities for larger epidemiological studies to monitor the FD outbreaks. Further research is necessary to verify the existence of alternative vectors that could

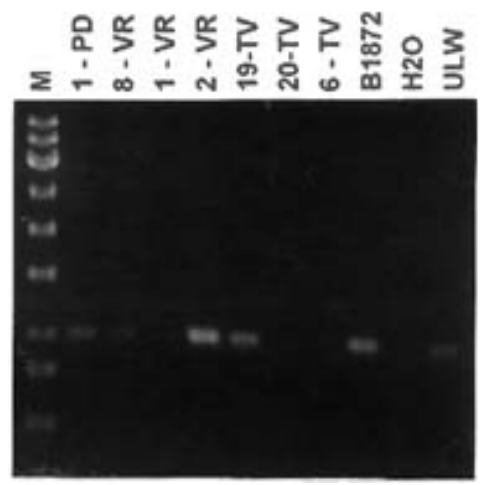

Fig. 6. Agarose gel of direct polymerase chain reaction (PCR) with primer pair 16R758f/ V1731r on grapevine samples indicated following numbers in Table 1. ULW, elm yellows (EU); PD, Padova; VR, Verona; TV, Treviso. $\mathrm{M}$, marker 1-kb DNA ladder. 
contribute to the spread of one or both FD strains involved in outbreaks of this quarantine disease.

\section{ACKNOWLEDGMENTS}

We thank Dennis Schaff, Plant Science Institute, Department of Biology, University of Pennsylvania, Philadelphia, for the sequencing; Elisabeth Boudon Padieu and Denis Clair, Unité de Recherches sur les Phytoplasmes, INRA, Dijon, France, for kindly providing FD strain B1872 and for preparing this control strain and testing some of the FD isolates from Italy, respectively. We also are grateful to M. Borgo, Istituto Sperimentale per la Viticoltura, MiPA, Conegliano, Treviso, Italy, for providing some of the FD strains from Treviso province. The research work was supported by a grant of the Regione Veneto-Serviszio Fitosanitario Regionale, Verona, Italy, on "Intervento per la moltiplicazione di materiale vegetale della vite non contaminato dalla flavescenza dorata."

\section{LITERATURE CITED}

1. Albanese, G., Davis, R. E., Granata, G., Dally, E. L., Santuccio, T., and Tessitori, M. 1996. DNA-based analysis to detect and identify phytoplasmas in yellows-diseased grapevines in Sicily. Petria 6:65-76.

2. Alma, A., Bosco, D., Danielli, A., Bertaccini, A., Vibio, M., and Arzone, A. 1997. Identification of phytoplasmas in eggs, nymphs and adults of Scaphoideus titanus Ball reared on healthy plants. Insect Mol. Biol. 6(2):115121.

3. Alma, A., Davis, R. E., Vibio, M., Danielli, A., Bosco, D., Arzone, A., and Bertaccini, A. 1996. Mixed infection of grapevines in Northern Italy by phytoplasmas including $16 \mathrm{~S}$ rRNA RFLP subgroup 16SrI-B strains previously unreported in this host. Plant Dis. 80:418-421.

4. Bertaccini, A., Borgo, M., Martini, M., Mori, N., Murari, E., Posenato, G., Sancassani, P., Sartori, S., and Vibio, M. 1998. Continuano le epidemie di giallumi. Inf. Agrario 15:85-90.

5. Bertaccini, A., Murari, E., Vibio, M., Danielli, A., Davis, R. E., Borgo, M., Consolaro, R., and Sancassani, P. 1996. Identificazione molecolare dei fitoplasmi presenti in viti affette da giallumi nel Veneto. Inf. Agrario 20:55-59.

6. Bertaccini, A., Vibio, M., Schaff, D. A., Murari, E., Martini, M., and Danielli, A. 1997. Geographical distribution of elm yellows-related phytoplasmas in grapevine Flavescence dorée outbreaks in Veneto (Italy). ICVG Meeting, 12th. Lisbon, Portugal. pp. 57-58.

7. Bertaccini, A., Vibio, M., and Stefani, E. 1995. Detection and molecular characterization of phytoplasmas infecting grapevine in Liguria (Italy). Phytopathol. Mediterr. 34:137141.

8. Bianco, P. A., Davis, R. E., Casati, P., and Fortusini, A. 1996. Prevalence of aster yellows (AY) and elm yellows (EY) group phytoplasmas in symptomatic grapevines in three areas of northern Italy. Vitis 35:195-199.

9. Bianco, P. A., Davis, R. E., Prince, J. P., Lee, I.-M., Gundersen, D. E., Fortusini, A., and Belli, G. 1993. Double and single infections by aster yellows and elm yellows MLOs in grapevines with symptoms characteristic of Flavescence dorée. Riv. Patol. Veg. S.V. 3:69-
82.

10. Boudon-Padieu, E., Daire, X., Clair, D., Lavina, A., Batlle, A., Reinert, W., and Maixner, M. 1997. Differentiation of grapevine phytoplasmas in the elm yellows and the stolbur group with the use of RFLP of non-ribosomal DNA. ICVG Meeting, 12th. Lisbon, Portugal. pp. 55-56.

11. Caudwell, A. 1957. Deux années d'études sur la Flavescence dorée, nouvelle maladie grave de la vigne. Ann. Amelior. Plant. 4:359-393.

12. Daire, X., Clair, D., Kuszala, C., and BoudonPadieu, E. 1994. Detection and differentiation of grapevine yellows MLOs. IOM Lett. 3:253-254.

13. Daire, X., Clair, D., Larrue, J., and BoudonPadieu, E. 1997. Detection and differentiation of grapevine yellows phytoplasmas belonging to elm yellows group and to the stolbur subgroup by PCR amplification of non-ribosomal DNA. Eur. J. Plant Pathol. 103:507-514.

14. Daire, X., Clair, D., Larrue, J., BoudonPadieu, E., Alma, A., Arzone, A., Carraro, L., Osler, R., Refatti, E., Granata, G., Credi, R., Tanne, E., and Caudwell, A. 1993. Occurrence of diverse MLOs in tissues of grapevine affected by grapevine yellows in different countries. Vitis 32:247-248.

15. Danielli, A., Bertaccini, A., Bosco, D., Alma, A., Vibio, M., and Arzone, A. 1996. May evidence of 16SrI-group-related phytoplasmas in eggs, nymphs and adults of Scaphoideus titanus Ball suggest their transovarial transmission? IOM Lett. 4:190-191.

16. Davis, R. E., Dally, E. L., Bertaccini, A., Lee, I.-M., Credi, R., Osler, R., Savino, V., Carraro, L., Di Terlizzi, B., and Barba, M. 1993. Restriction fragment length polymorphism analyses and dot hybridizations distinguish mycoplasmalike organisms associated with flavescence dorée and Southern European grapevine yellows disease in Italy. Phytopathology 83:772-776.

17. Davis, R. E., Dally, E. L., Tanne, E., and Rumbos, I. C. 1997. Phytoplasmas associated with grapevine yellows in Israel and Greece belong to the stolbur phytoplasma subgroup, 16SrXII-A. J. Plant Pathol. 79:181-187.

18. Gibb, K. S., Padovan, A. C., and Mogen, B. D. 1995. Studies on sweet potato little-leaf phytoplasma detected in sweet potato and other plant species growing in Northern Australia. Phytopathology 85:169-174.

19. Lee, I.-M., Bertaccini, A., Vibio, M., and Gundersen, D. E. 1995. Detection of multiple phytoplasmas in perennial fruit trees with decline symptoms in Italy. Phytopathology 85:728-735.

20. Lee, I.-M., Davis, R. E., Sinclair, W. A., DeWitt, N. D., and Conti, M. 1993. Genetic relatedness of mycoplasmalike organisms detected in Ulmus spp. in the United States and Italy by means of DNA probes and polymerase chain reactions. Phytopathology 83:829-833.

21. Lee, I.-M., Gundersen, D. E., Hammond, R. W., and Davis, R. E. 1994. Use of mycoplasmalike organism (MLO) group-specific oligonucleotide primers for nested-PCR assays to detect mixed-MLO infections in a single host plant. Phytopathology 84:559566.

22. Lee, I.-M., Gundersen-Rindal, D. E., Davis, R. E., and Bartoszyk, I. M. 1998. Revised classification scheme of phytoplasmas based on RFLP analyses of 16SrRNA and ribosoma protein gene sequences. Int. J. Syst. Bacteriol. 48:1153-1169.

23. Lee, I.-M., Pastore, M., Vibio, M., Danielli, A., Attathom, S., Davis, R. E., and Bertaccini, A. 1997. Detection and characterization of a phytoplasma associated with annual blue grass (Poa annua) white leaf disease in Southern Italy. Eur. J. Plant Pathol. 103:251254.

24. Maixner, M., Ahrens, U., and Seemüller, E. 1995. Detection of the German grapevine yellows (Vergilbungskrankheit) MLO in grapevine, alternative hosts, and a vector by a specific PCR procedure. Eur. J. Plant Pathol. $101: 241-250$

25. Marcone, C., Ragozzino, A., and Seemüller, E. 1997. Identification and characterization of the phytoplasma associated with elm yellows in southern Italy and its relatedness to other phytoplasmas of the elm yellows group. Eur. J. For. Pathol. 27:45-54

26. Martini, M., Vibio, M., Sfalanga, A., and Bertaccini, A. 1998. Molecular and ecological diversity of phytoplasmas belonging to the elm yellows group in Italy towards their tentative epidemiology. IOM Conf., 12th. Sidney, Australia. p. 130

27. Padovan, A. C., Gibb, K. S., Bertaccini, A., Vibio, M., Bonfiglioli, R. G., Magarey, P. A., and Sears, B. B. 1995. Molecular detection of Australian grapevine yellows phytoplasma and comparison with grapevine yellows phytoplasmas from Italy. Aust. J. Grape Wine Res. 1:25-31.

28. Posenato, G., and Girolami, V. 1994. Diffusione ed evoluzione della flavescenza dorata della vite nell'area del Soave. Inf. Agrario 22:57-60

29. Prince, J. P., Davis, R. E., Wolf, T. K., Lee, I.M., Mogen, B. D., Dally, E. L., Bertaccini, A., Credi, R., and Barba, M. 1993. Molecular detection of diverse mycoplasmalike organisms (MLOs) associated with grapevine yellows and their classification with aster yellows, X-disease, and elm yellows MLOs. Phytopathology 83:1130-1137.

30. Refatti, E. 1993. La flavescenza dorata ed altri giallumi della vite, stato attuale delle conoscenze e problemi di lotta. Eurovite'93 Ersa 23-30.

31. Schaff, D. A., Lee, I.-M., and Davis, R. E. 1992. Sensitive detection and identification of mycoplasmalike organisms by polymerase chain reactions. Biochem. Biophys. Res. Comm. 186:1503-1509.

32. Schneider, B., Seemüller, E., Smart, C. D., and Kirkpatrick, B. C. 1995. Phylogenetic classification of plant pathogenic mycoplasmalike organisms or phytoplasmas. Page 369-380 in: Molecular and Diagnostic Procedures in Mycoplasmology. Vol. 2. S. Razin and J. G. Tully, eds. Academic Press, New York.

33. Seemüller, E., Marcone, C., Lauer, U., Ragozzino, A., and Göschl, M. 1998. Current status of molecular classification of the phytoplasmas. J. Plant Pathol. 80:3-26.

34. Zhang, Y.-P., Uyemoto, J. K., and Kirkpatrick, B. C. 1995 . A rapid, small scale procedure for extracting virus, viroid, MLO and bacterial nucleic acids from plants for analysis by PCR (Abstr.) Phytopathology 85:1205. 